\title{
World Social and Economic Development in the Theory of Ternary Counterpoints
}

\author{
Mokiy Vladimir, PhD \\ Lukyanova Tatyana, Leading Specialist \\ Institute for Transdisciplinary Technologies, \\ Kabardino-Balkarian Republic, Nalchik, RF
}

Doi:10.19044/esj.2019.v15n23p12～URL:http://dx.doi.org/10.19044/esj.2019.v15n23p12

\begin{abstract}
The need to adapt the process of knowledge of the world to the achievement of socially meaningful goals by society has contributed to the formation and consolidation at the genetic level of the corresponding megastructure of neuron connections in the brain. The presence of different types of knowledge indicates the presence of different subspecies of people. Subspecies of people differ in the mega-construction of neuronal connections in the brain. This particular mega-structure of neuron connections allows you to focus on the formation and perception of a strictly defined type of knowledge in the process of knowing the world. The use of methodology of the systems transdisciplinary approach makes it possible to identify the natural mechanism of interaction between various types of knowledge and various subspecies of people. This mechanism is implemented in the framework of the Ternary Counterpoint. The task of the Ternary Counterpoint is to provide "gain axioms". Axioms of reinforcement contribute to the addition of a set of axioms that define the essence of the types of knowledge and subspecies of people. They are able to set and control, as well as maintain and develop this essence. The interaction within the framework of the Ternary Counterpoint is carried out by special people-hybrids. These people possess a hybrid megadesign of neuron connections in the brain. Such people began to be called generalists. It is possible that the emergence of departments for the training of generalists will become a distinctive feature of third-generation institutions.
\end{abstract}

Keywords: Systems worldview, Knowledge, Transdisciplinarity, Systems transdisciplinary approach, Generalists

\section{Introduction}

Talking about the nature and boundaries of scientific knowledge and the significant role it plays in the sustainable development of modern society, 
two circumstances must be taken into account. First, outside the general starting point about knowledge (axioms) and about the peculiarities of the consciousness of the people who form this knowledge, the reasoning on this topic will be "arguments from the middle". Physicist W. Heisenberg stated that in the absence of a common starting point, we always have to start somewhere from the middle and, when discussing reality, to use concepts that only gradually acquire a certain meaning due to the use thereof (Ponomarev, 2005). Second, the mathematician K.F. Godel argued that the logical completeness of any system of axioms about scientific knowledge and people cannot be proven within the framework of this system. To prove or disprove it, additional axioms (axioms of amplification) are required (Raatikainen, 2015). The axiom is a starting point taken without any proof. Subsequently, this initial position is the basis of the evidence of all subsequent statements within the framework of this theory. Therefore, to successfully solve the problems of the axiomatization of the general idea of knowledge, in order to determine their logical boundaries, it is necessary to understand the difference between the people who create this knowledge and also find out how the axioms of amplification are formed.

Subsequently, the answers to these questions can be received using a systems transdisciplinary approach.

\section{Systems Transdisciplinary Approach: The Concept and Methodology}

The systems transdisciplinary approach is a way to correctly isolate and model a complex object as a single transdisciplinary system. At the same time, a set of objects pursuing a common goal is associated with a functional ensemble of objects. The image of the transdisciplinary system in this case is associated with the general order, which determines the unity of the functional ensemble of objects. This approach allows the use of a special transdisciplinary concept, philosophical basis, and methodology in the study. The united world is the one world. Any objects at all levels of the reality of a one world are its natural elements and fragments. Therefore, the main condition for the existence of a one world is the existence of a universal order in it. As the name implies, it follows that this objective order must manifest itself everywhere: in every element/fragment of this world and in every interaction of these elements/fragments at every level of reality. As a result, the same order should ensure the achievement of activity goals and results of all these elements/fragments. In addition, it should synchronize these goals and results. For this reason, a single world is a One Orderly Medium.

The major attribute of this One Orderly Medium is the potency, which is naturally present in it. Potency is the prospective futurity of the One Orderly Medium-her latent force. Within the framework of the unicentrism concept, the definitions of these philosophical categories are as follows: 
Space - as a form of existence of potency of One Orderly Medium; Information - as a form of development of potency of One Orderly Medium; Time - as a form of transformation of potency of One Orderly Medium.

However, the universal order plays the role of a transdisciplinary system in relation to the forms of potentiality of a single world. This particular universal order manifests in the forms themselves, in the interaction of these forms, as well as determines their unity.

The philosophical basis of the systems transdisciplinary approach is "centrism of unity" (unicentrism). In a broad sense, unicentrism is a position in philosophy and in science that is based on the problem of the correlation between the single and its fragments. This position is based on the isomorphism of the universal order of the structure of fragments of space, and the attributes of information and periods of time that determine the one and only of the world. All models have a similar structure fragments of space, attributes of information, and periods of time. In this case, the image of the transdisciplinary system is revealed by means of models of spatial, informational, and temporal "units of order". In a narrower sense, the unicentrism is understood as the "philosophy of unity" developed by the Russian philosopher, Vladimir Mokiy. He also in 2010 introduced the term "unicentrism" (Mokiy, 2019b).

Methodological features of "unit of order" models can be seen from their definitions. Systems transdisciplinary model of spatial unit of order is a logically complete structure of space fragments in the transdisciplinary system. It allows substantiation of physical boundaries within which the original potency of an object and a functional ensemble of objects exist (see Figures 1a, 1b).

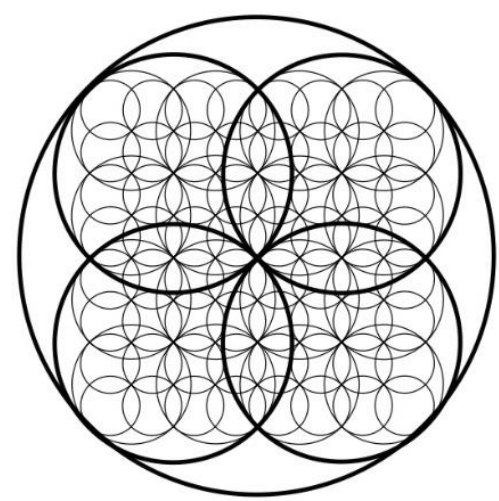

Figure 1a. Systems Transdisciplinary Model of Spatial Unit of Order 


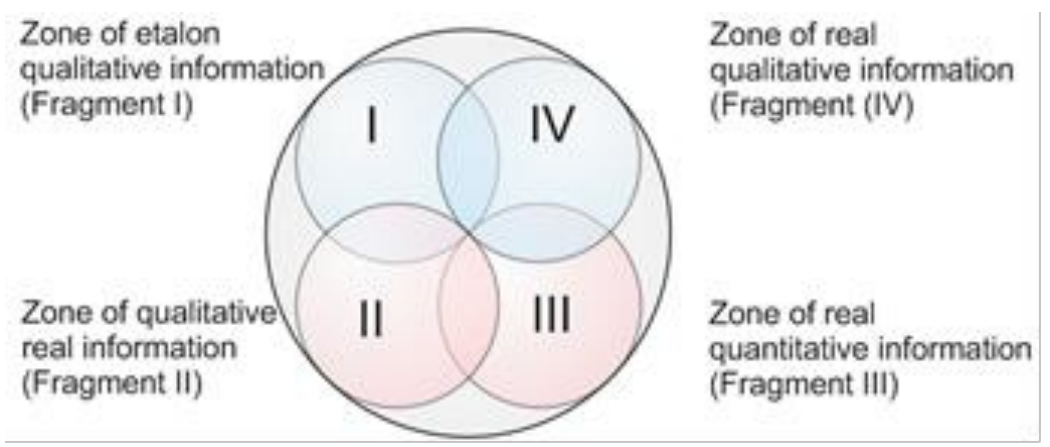

Figure 1b. Scheme of Zones of Major Functional Predisposition of Spatial Unit of Order.

Systems transdisciplinary model of informational unit of order is a logically complete sequence of attributes of complete information in the transdisciplinary system. It allows the substantiation of logical boundaries of expression within which the original potency of an object and a functional ensemble of objects exist (see Figure 2).

\begin{tabular}{|l|l|c|c|}
\hline \multicolumn{4}{|c|}{ Complete information } \\
\hline \multicolumn{2}{|c|}{ Information of quantitative type } & Information of qualitative type \\
\hline $\begin{array}{l}\text { Information } \\
\text { of quantitative- } \\
\text { quantitative } \\
\text { type }\end{array}$ & $\begin{array}{l}\text { Information } \\
\text { of quantitative- } \\
\text { qualitative } \\
\text { type }\end{array}$ & $\begin{array}{l}\text { Information } \\
\text { of qualitative- } \\
\text { quantitative } \\
\text { type }\end{array}$ & $\begin{array}{l}\text { Information } \\
\text { of qualitative- } \\
\text { qualitative } \\
\text { type }\end{array}$ \\
\hline & Attributes of complete information & \\
\hline
\end{tabular}

Figure 2. Systems Transdisciplinary Model of Information Unit of Order

Systems transdisciplinary model of temporal unit of order is a logically complete sequence of time periods in the system. It allows the substantiation of duration of transformation within which the original potency of object and a functional ensemble of objects exist (see Figure 3) (Mokiy \& Lukyanova, 2017)

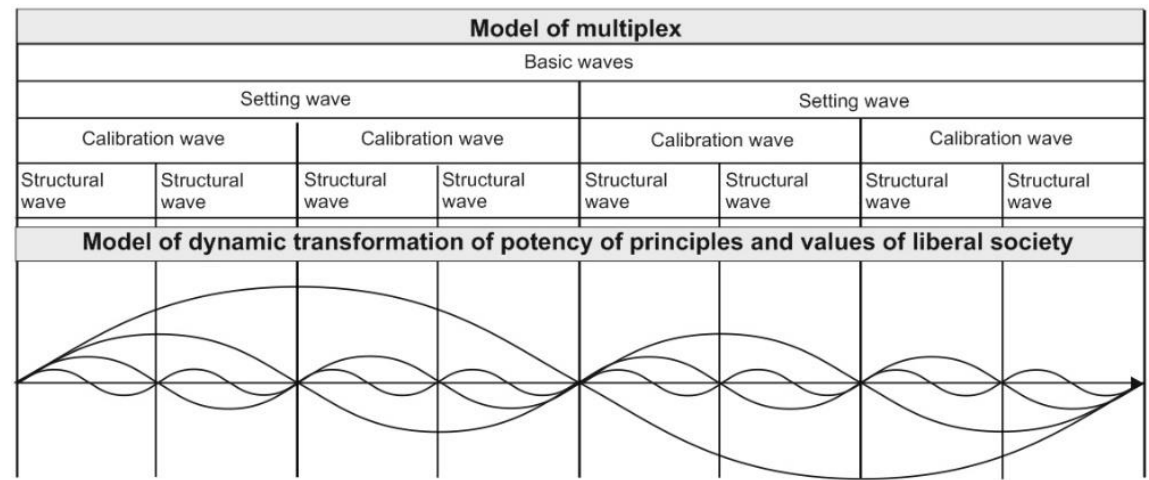

Figure 3. Systems Transdisciplinary Model of Temporal Unit of Order. 
Furthermore, the context space model is one of the three basic models of a transdisciplinary system. This model is called a spatial unit of order. It reflects the form of existence of potency (perspective future) of the object of study elements. Therefore, this model is more suitable for justifying the axioms.

\section{Particularity of the Higher Nervous Activity of the Modern Man}

Knowledge is a systematic result of continuous human interaction with the outside world. In this case, a promising starting point for arguments about knowledge is the axiom of the unity of the world and man. Being a natural element of the world, man is in a state of total interaction with it. This interaction is carried out simultaneously in two modes: reflection and imaging (Mokiy, 2015b).

Reflection of the world is manifested in the human body over the course of natural physical and chemical processes. These processes, which are not conceived by man, reflect the natural order of transformation of matter in the world in the way that a mirror does, i.e. without distortion. Reflection processes end with results that have the status of higher values. The role of higher values is played by Ribonucleic acid (RNA) and Deoxyribonucleic acid (DNA) molecules. These molecules accumulate in themselves information about the structure of the human body, its internal organs, and the nature and intensity of the physical and chemical processes at all levels of the body. Information embodied in the construction of RNA and DNA acquires the status of objective knowledge. However, such knowledge determines the usefulness of man for the processes of directed transformation of planetary matter.

Imaging of the world is carried out by physical and chemical processes occurring in the central nervous system of man. These processes endow a person with rational activity and psyche (Mazilov, 2017). The results of the mental functions of man (thinking, consciousness, mind) play the role of the highest values of the world imaging processes. More precisely, the highest values of these processes are the ideas that form the basis of the landmark worldview of man and the principles and norms of morality that correspond to this worldview.

Thus, the mechanisms of reflection and imaging demonstrate the internal unity of the physical and chemical processes of the world, the planet and man. In the context of this statement, the worldview should be considered as a natural mechanism that supports the existence of man in the outside world. Consequently, the sequence of replacing the worldviews, as well as the dominant ideas and principles of morality, can be derived from the model of the development of the world and the planetary nature.

The principles for constructing such models have been developed and practically tested in the framework of the systems transdisciplinary approach 
(Mokiy, 2013, 2016, 2019a; Mokiy \& Lukyanova, 2018). In accordance with these models, the required logically completed period is determined from one (key) model of the world development. The natural acceleration of the development process in such a model is represented by successively shortened periods. The numerical parameters of the key model are calculated on the basis of the modern Earth chronology. This circumstance allowed us to reveal the planet development fragment, in which terrestrial humanity plays a significant role. One of these logically designed periods has a duration from 10252 B.C. to 2688 A.D. Due to the nature of the events, this period was called the period of the formation of the features of the higher nervous activity of Man Truly Reasonable.

The identity of the senses allows people to have a uniform style of thinking. This style corresponds to the laws of logic, as well as certain methodological norms and rules. This style is denoted by the term "rationality". From a historical perspective, rationality is a way of adapting the process of knowledge of the world to the achievement of socially meaningful goals by a society. Therefore, the historical perspective of the selected period consists of different, logically justified stages.

In view of the above arguments, it is logical to assume that each of such stages corresponds to the characteristic features of higher nervous activity (thinking, consciousness and intelligence) of man. The need to adapt the process of cognition of the world to the achievement of milestone socially meaningful goals has contributed to the formation and consolidation at the genetic level of the corresponding mega-structure of neuron connections in the human brain. Therefore, the beginning of each stage in the model was accompanied by two important events. First, by the characteristic revolution, which is Neolithic, Civilizational, Ethnic, and Industrial. Second, the formation of the main subspecies of Man Truly Reasonable corresponding to the character of these revolutions: Sedentary Man, Social Man, Humanistic Man, and Liberal Man (see Figure 4).

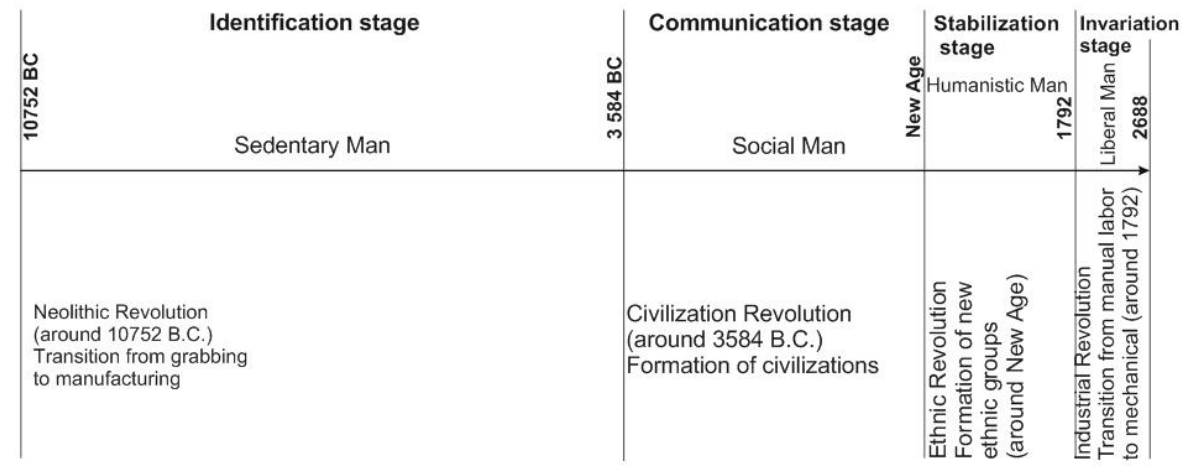

Figure 4. The Model of the Historical Perspective of the Formation of Man Truly Reasonable. 
This circumstance suggests that after 1792, modern humanity consists of people, and the peculiarities of the higher nervous activity were determined by four basic mega-constructions of connections of neurons of the brain. Thus, the relationships of these subspecies of Man Truly Reasonable are shown in the contextual space model (see Figure 5).

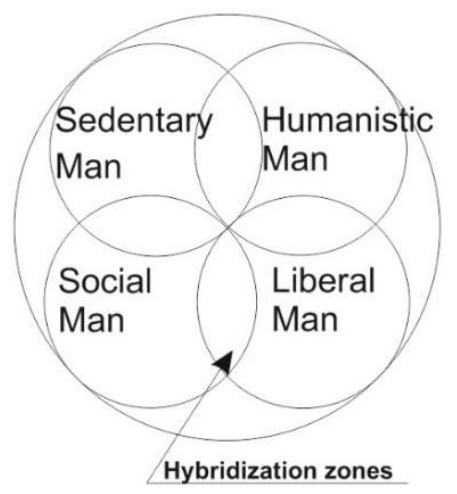

Figure 5. The Context Model of Man Truly Reasonable Subspecies (Systems Transdisciplinary Model of Spatial Unit of Order).

\section{Basic Types of Knowledge of Modern Humanity}

In the process of forming a staged worldview, generalization of various subjective opinions about the world, about the need and purpose of man, about the methods and results of human activity, and about the principles and norms of morality took place. Many opinions arose due to the individuality of man. Individuality is manifested in the sensual interpretation of the content of information that man receives about the world. In accordance with K.F. Gauss's "law of normal distribution", subjective opinions of many people are distributed in a combination of senses. The distribution result demonstrates a bell-shaped model, a Gaussian. The Gaussian divides opinions into two types: Subjective and Inter-subjective opinions. Inter-subjective opinions, the content perceived, maintained and used by most people, play the significant role of knowledge (see Figure 6).

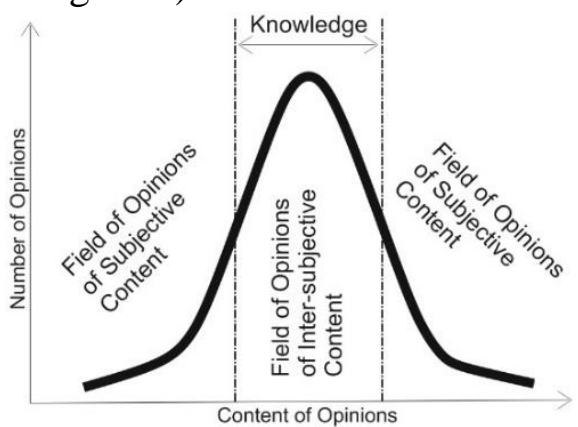

Figure 6. Normal Distribution of Subjective Opinions (Gaussian) 
Opinions and knowledge are classified according to the need to justify them. "The basis of the first group consists of opinions and knowledge that do not require justification. We accept these opinions and knowledge without any special reasoning. They fully meet our sense of life, and which we do not want to question. The basis of the second group consists of opinions and knowledge that require justification. Moreover, it is not only the fact of justification that is important here, but also the means of obtaining information, as well as the methods of their justification" (Nikiforov, 2009).

The generalization of knowledge through the context space model allows us to draw the following conclusion. Knowledge that does not require its justification includes knowledge of an Unconditional (absolute) type and knowledge of an Intuitive type. Knowledge that requires its justification through logical and empirical evidence obtained using inductive or deductive methods should include knowledge of the Speculative type and, accordingly, knowledge of the Empirical type (see Figure 7).

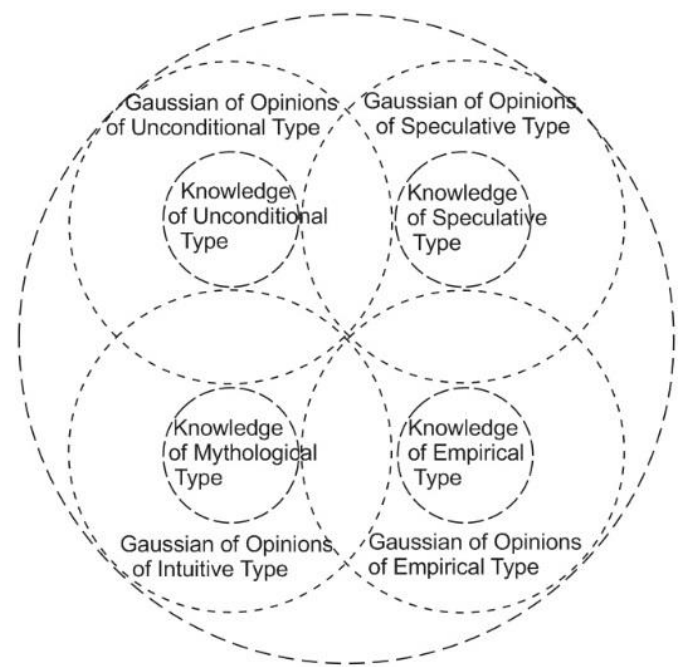

Figure 7. Model of Gaussian Contextual Space of Opinions and Knowledge of Various Types.

The combination of models of the context space of the subspecies of people of Man Truly Reasonable and the Gaussian has made it possible to detect their internal connection. For example, knowledge that does not require its justification was formed mainly by Sedentary Man and Social Man.

The transition from a herd to a clan, the initial formation of the foundations of morality, and the preservation of intra-generic relations implied the existence of Sedentary Man in environment of opinions and knowledge of Unconditional type. The transition to inter-clan relations, the search for scenarios of a sustainable society, and the foundations of social morality 
assumed the existence of Social Man in environment of opinions and knowledge of the Intuitive type.

It is worth noting that knowledge that does not require its justification did not imply an assessment and preservation of the value of a "lively and sensual" human opinion, and, consequently, the value of Man, his personal life, and life in general. However, with the advent of new ethnic groups, the value of Man himself and the value of his life came to the fore. These circumstances contributed to the fact that for the existence of Humanistic Man and Liberal Man, an environment of opinions and knowledge requiring its justification was required. For Humanistic Man, opinions and knowledge of the Speculative type have become the bane of such an environment. For a Liberal Man, Empirical type opinions and knowledge became dominant in such an environment.

\section{Axioms of Amplification of Knowledge of Modern Society}

As suggested by Lev Gumilyov, the "collectives" of people of modern society is naturally formed on the basis of the original stereotype of behavior and existing as social landscape systems, oppose themselves to other similar systems, based on the feeling of complementarity (Alekseeva, 2010).

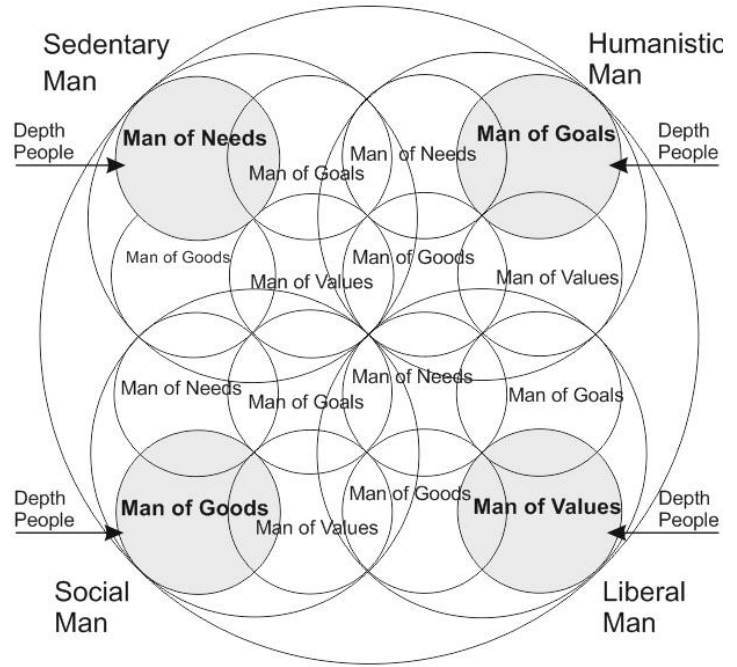

Figure 8. The Disaggregated Model of the Context Space of the Man Truly Reasonable Subspecies.

The disaggregated model of the context space of the Man Truly Reasonable subspecies allows demonstration of this complementarily (mutual addition) (see Figure 8).

This model covers the whole potency (perspective future) of the Man Truly Reasonable species. In this model, each subspecies is represented by its own carriers (sub-species): Man of Needs, Man of Goods, Man of Values, and 
Man of Goals. The mega-constructions of neuron connections in the brain of these subspecies led to a strictly defined interpretation of the content of the concepts: Needs, Goods, Values, and Goals. They determined the assessment of the life of society through the prism of this content (see Table 1). Without taking this circumstance into account, the attempts of the specialists to make general classifications of these concepts on the basis of some general content have so far failed.

Table 1. Interpretation of the Content of the Terms by Subspecies of Man Truly Reasonable

\begin{tabular}{||c|c|c|c|c||}
\hline $\begin{array}{c}\text { Subspecies of } \\
\text { Man Truly } \\
\text { Reasonable }\end{array}$ & Needs & Goods & Values & Goals \\
\hline \hline Sedentary Man & $\begin{array}{c}\text { Vitally } \\
\text { important } \\
\text { limited }\end{array}$ & $\begin{array}{c}\text { Connection } \\
\text { with people and } \\
\text { nature }\end{array}$ & $\begin{array}{c}\text { Products made by } \\
\text { nature and man }\end{array}$ & $\begin{array}{c}\text { Perception of } \\
\text { truth }\end{array}$ \\
\hline \hline Social Man & $\begin{array}{c}\text { Status } \\
\text { unlimited }\end{array}$ & $\begin{array}{c}\text { Products } \\
\text { having value }\end{array}$ & Social prestige & $\begin{array}{c}\text { Desire for } \\
\text { wealth }\end{array}$ \\
\hline \hline Humanistic Man & $\begin{array}{c}\text { Vitally } \\
\text { important } \\
\text { limited }\end{array}$ & $\begin{array}{c}\text { Harmonious } \\
\text { relationship } \\
\text { between people } \\
\text { and nature }\end{array}$ & $\begin{array}{c}\text { Functional } \\
\text { ensembles (social } \\
\text { and natural) }\end{array}$ & $\begin{array}{c}\text { Achieving } \\
\text { justice }\end{array}$ \\
\hline \hline Liberal Man & $\begin{array}{c}\text { Status } \\
\text { unlimited }\end{array}$ & $\begin{array}{c}\text { Affordable } \\
\text { services }\end{array}$ & $\begin{array}{c}\text { Utility of services, } \\
\text { products, } \\
\text { relationships and } \\
\text { connections }\end{array}$ & $\begin{array}{c}\text { Desire for } \\
\text { welfare }\end{array}$ \\
\hline \hline
\end{tabular}

How is sustainable coexistence of one's own subspecies within each subspecies of Man Truly Reasonable achieved? What is the sustainable coexistence of the main subspecies of Man Truly Reasonable? To answer these questions, it is necessary to refer to the concept of a "Depth People". The Depth People are the bearer of the original social and cultural codes of human subspecies. According to V. Surkov the creator of this term, "The Depth People are always hardnosed, inaccessible to sociological polls, agitation, threats, and other methods of direct study and influence. There are other types of people who are actively involved in public events such as meetings, conflicts, elections, economic experiments. The Depth People participate in such events, but are somewhat detached, do not show on the surface and live in their own depths with a completely different life. Two national lives, superficial and deep, sometimes live in opposite directions, sometimes coinciding, but never merge into one" (Surkov, 2019).

The calculation of the depth people in each major subspecies of Man Truly Reasonable occurs by overlaying isomorphic models of the context space of the appropriate type of man (see Figure 5) and the corresponding type of knowledge (see Figure 7). In the disaggregated model of the context of the 
subspecies of Man Truly Reasonable, the subspecies, which have no direct interaction with neighboring subspecies of man, will play the role of Depth People (see Figure 8). For Sedentary Man and Social Man, these non-direct interactions will form their worldview mainly on opinions and knowledge that do not require justification. For example, for the society of Sedentary Man, the role of Depth People will be played by Man of Needs. For the society of Social Man, the role of Depth People will be played by Man of Goods. In turn, for Humanistic Man and Liberal Man, who have no direct interaction subspecies, they will shape their worldview mainly on opinions and knowledge that require justification. For the society of Humanistic Man, the role of Depth People will be played by Man of Goals. For the society of Liberal Man, the role of Depth People will be played by Man of Values.

Subsequently, the stable existence of subspecies within each major subspecies ensures the interaction of depth people with two neighboring subspecies. One of these subspecies professes knowledge that does not require justification. As a rule, this subspecies set and/or control the content of knowledge, on which the worldview of Depth People is based. Another subspecies profess knowledge that requires justification. This subspecies supports and/or develop the knowledge on which the worldview of the Depth People is based. Such a set of subspecies of people received the name of the Ternary Counterpoint. Thus, counterpoint (lat. punctum, literally - point vs. point) is a simultaneous complementary combination of two or more independent logical directions.

The Ternary Counterpoint is supplemented by a single a-Counterpoint. The role of a-Counterpoint is played by a subspecies that does not directly interact with the Depth People. In this respect, it has the necessary degree of freedom that ensures the openness of the context space of each main subspecies for the general context space of Man Truly Reasonable. In terms of modern sociology, single a-Counterpoints play the role of carriers of ideas and principles of globalization. The Ternary Counterpoints and aCounterpoints of the main subspecies of Man Truly Reasonable, ensuring their sustainable existence and coexistence, are presented in Table 2.

Table 2. The Ternary Counterpoints of the Main Subspecies of Man Truly Reasonable

\begin{tabular}{|c|c|c|c|}
\hline $\begin{array}{c}\text { The basic element of } \\
\text { the Ternary } \\
\begin{array}{c}\text { Counterpoint } \\
\text { (Depth People) }\end{array}\end{array}$ & $\begin{array}{c}\text { The defining and/or } \\
\text { controlling element } \\
\text { of the Ternary } \\
\text { Counterpoint }\end{array}$ & $\begin{array}{c}\text { The supporting and } \\
\text { / or developing } \\
\text { element of the } \\
\text { Ternary } \\
\text { Counterpoint }\end{array}$ & A-Counterpoint \\
\hline $\begin{array}{c}\text { Sedentary Man: } \\
\text { Man of Needs }\end{array}$ & Man of Goods & Man of Goals & Man of Values \\
\hline
\end{tabular}




\begin{tabular}{|c|c|c|c|}
\hline $\begin{array}{c}\text { Social Man: } \\
\text { Man of Goods }\end{array}$ & Man of Needs & Man of Values & Man of Goals \\
\hline $\begin{array}{c}\text { Humanistic Man: } \\
\text { Man of Goods }\end{array}$ & Man of Needs & Man of Values & Man of Goods \\
\hline $\begin{array}{c}\text { Liberal Man: } \\
\text { Man of Values }\end{array}$ & Man of Goods & Man of Goals & Man of Needs \\
\hline
\end{tabular}

As part of the Ternary Counterpoint of the main subspecies of Man Truly Reasonable playing the role of modern society, the Depth People (the bearer of the social and cultural codes of humanity) are people belonging to the subspecies of Sedentary Man. The subspecies of Social Man sets up and/or control development of the worldview of modern society. The subspecies of Humanistic Man supports and/or develops the worldview of modern society. The subspecies of Liberal Man play the role of a-Counterpoint of modern society.

A-Counterpoints make open the contextual spaces for the organization and implementation of globalization processes. Therefore, one can only guess to what or to whom the modern human society will inevitably open up to? Probably, we should talk about the upcoming disclosure of humanity to a Planetary Vertical Functional Ensemble. During this time, people of one subspecies consistently accepted and united with people of other emerging subspecies. Probably, people from among the liberal society in their time will be able to unite the whole of human society with the planet.

The practical importance of the theory of Counterpoints for studying the stability of national and multinational states and state unions should be noted. The forthcoming retrospective studies should confirm the theoretical assumption that the condition for the sustainable social and economic development of these large objects is their composition in the image of a strictly defined Ternary Counterpoint.

\section{Conclusion}

What conclusions follow from the context models of all sorts of opinions and subspecies of Man Truly Reasonable?

Knowledge is the result of a conscious imaging of the world in the mind of man. In turn, the consciousness of each specific subspecies of Man Truly Reasonable will be focused on the formation and perception of the basic type of knowledge. It will be mainly satisfied with the content of axioms that are based on this type of knowledge. According to the context space model (see Figure 3), the axioms of amplification necessary for proving or refuting the logical completeness of basic axioms built on specific knowledge will belong 
to two types of opinions and knowledge that interact with it within the framework of the ternary counterpoint (see Table 3).

Table 3. Axioms of Amplification of the Basic Types of Knowledge

\begin{tabular}{|c|c|c|}
\hline $\begin{array}{l}\text { Axioms of amplification that } \\
\text { define and/or control the } \\
\text { logical completeness of the } \\
\text { axioms of basic knowledge }\end{array}$ & $\begin{array}{c}\text { The set of axioms of basic } \\
\text { knowledge, which are subject } \\
\text { to amplification (proof or } \\
\text { refutation) }\end{array}$ & $\begin{array}{c}\text { Axioms of amplification } \\
\text { that support and/or } \\
\text { develop the logical } \\
\text { completeness of the axioms } \\
\text { of basic knowledge }\end{array}$ \\
\hline $\begin{array}{l}\text { Intuitive type knowledge } \\
\text { axioms }\end{array}$ & $\begin{array}{l}\text { Unconditional type } \\
\text { knowledge axioms }\end{array}$ & $\begin{array}{l}\text { Speculative knowledge } \\
\text { axioms }\end{array}$ \\
\hline $\begin{array}{l}\text { Unconditional type } \\
\text { knowledge axioms }\end{array}$ & $\begin{array}{l}\text { Intuitive type knowledge } \\
\text { axioms }\end{array}$ & $\begin{array}{l}\text { Empirical type knowledge } \\
\text { axioms }\end{array}$ \\
\hline $\begin{array}{l}\text { Intuitive type knowledge } \\
\text { axioms }\end{array}$ & $\begin{array}{c}\text { Empirical type knowledge } \\
\text { axioms }\end{array}$ & $\begin{array}{c}\text { Speculative knowledge } \\
\text { axioms } \\
\end{array}$ \\
\hline $\begin{array}{l}\text { Unconditional type } \\
\text { knowledge axioms }\end{array}$ & $\begin{array}{c}\text { Speculative knowledge } \\
\text { axioms }\end{array}$ & $\begin{array}{c}\text { Empirical type knowledge } \\
\text { axioms }\end{array}$ \\
\hline
\end{tabular}

The content of each basic axiom and axiom of its amplification is the subject of study of many scientific disciplines. Therefore, when studying axioms and their interactions, it should be borne in mind that the same axiom in a particular case may be either the basic axiom or the axiom of amplification.

No less important point in the study of amplification axioms is the possibility of their natural integration. The conceptual possibility of such integration is provided by the model of the context space of opinions and knowledge of the transdisciplinary type (see Figure 9).

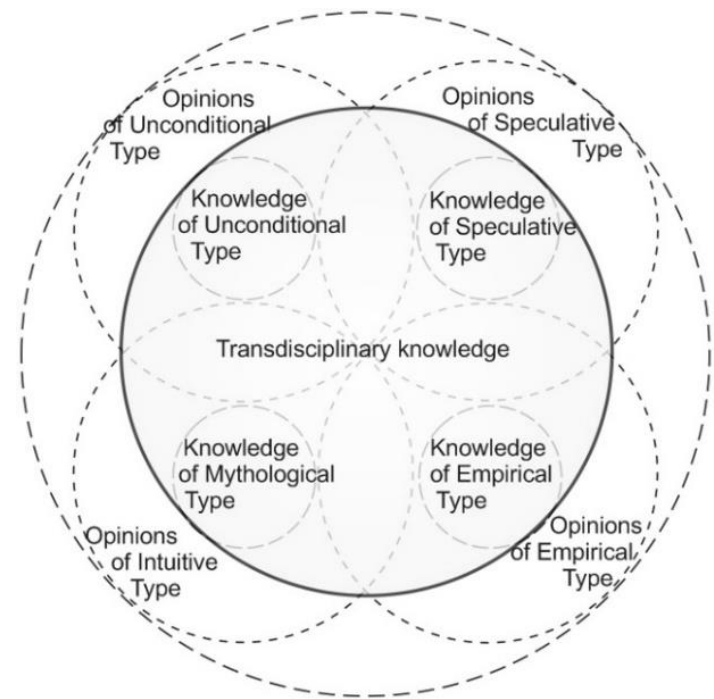

Figure 9. Model of the Context Space of Opinions and Knowledge of the Transdisciplinary

Type (Gaussian Knowledge of the Transdisciplinary Type). 
This model demonstrates the unity of various types of knowledge and subjective opinions that are complementary to such knowledge. To avoid the existing methodological problems of interdisciplinary interaction, this knowledge and opinions are pre-systematized. Systematization is carried out by means of models of a systems transdisciplinary approach: models of spatial, temporal and information units of order. Due to such systematization, knowledge and opinions of various types acquire conformity with the general attributive order, which conditions the unity of the world, the planet, society, and man (Mokiy, 2015a).

Thus, the axioms that looked earlier as separate elements of the system in its traditional sense were able to interpret their content and significance from the standpoint of their internal unity. Therefore, subsequent studies of the content and interaction of these axioms within the framework of the corresponding contextual space model will make it possible to re-evaluate the concepts of existing economic theories. It would also help to explain the natural causes and mechanisms of the alternation of world social and economic orders in the past and the future. It is important to note that the procedure for justifying the axioms of amplification was observed for each of the main subspecies of Man Truly Reasonable (see Table 4).

Table 4. Subspecies of Man Truly Reasonable Providing Axioms for Amplification of the Aggregate of Axioms of Basic Subspecies of Man.

\begin{tabular}{|c|c|c|}
\hline $\begin{array}{c}\text { Amplification axioms that } \\
\text { define and/or control the } \\
\text { logical completeness of the } \\
\text { axioms of the basic } \\
\text { subspecies of Man Truly } \\
\text { Reasonable }\end{array}$ & $\begin{array}{c}\text { Aggregate of the axioms of the } \\
\text { basic subspecies of Man Truly } \\
\text { Reasonable, which are subject to } \\
\text { amplification (proof or } \\
\text { refutation) }\end{array}$ & $\begin{array}{c}\text { Amplification axioms that } \\
\text { support and/or develop the } \\
\text { logical completeness of the } \\
\text { axioms of the basic } \\
\text { subspecies of Man Truly } \\
\text { Reasonable }\end{array}$ \\
\hline Axioms of Social Man & Axioms of Sedentary Man & Axioms of Humanistic Man \\
\hline Axioms of Sedentary Man & Axioms of Social Man & Axioms of Liberal Man \\
\hline Axioms of Social Man & Axioms of Liberal Man & Axioms of Humanistic Man \\
\hline Axioms of Sedentary Man & Axioms of Humanistic Man & Axioms of Liberal Man \\
\hline
\end{tabular}

In conclusion, it should be noted that the presented models and tables demonstrate an Axiomatic Methodological Construction. This construction allows you to see the entire mosaic of elements as a whole, which sets the meaning and characteristic features of the content of a landmark worldview, as well as ideas and principles of morality corresponding to this worldview. In other words, this construction extremely generalizes the diverse real life of modern society. 
Strangely enough, it is this methodological structure that proves the impossibility of solving complex multifactor problems through the traditional interdisciplinary interaction of deeply integrated specialists from different scientific disciplines. This is due to the fact that these specialists belong to different subspecies of people, and it is inevitably internally focused on the use of only certain types of knowledge and methods for justification thereof. Therefore, you can observe such a situation in a creative team. One specialist will encourage you to look for new approaches to solving complex multifactor problems of modern society, but his colleague will argue that any problems can be solved by a good business plan and money for its implementation.

Therefore, an extremely high level of generalization of the subspecies of people, types of knowledge, and the content of axioms suggests the use of special specialists and generalists to work with them. The main feature of the generalists is their ability to perceive, evaluate, and interpret the various knowledge and opinions belonging to areas of their "hybridization", which is within the framework of the corresponding counterpoint. To do this, they should be able to freely use the knowledge of various types and to operate it within the framework of the scientific methodology, including within the framework of the system and transdisciplinary approach. Ludwig von Bertallanfi, one of the founders of the general theory of systems, argued that generalists must necessarily be part of every interdisciplinary team. In addition, it can be argued that one of the priorities of modern higher education is not only to seek the ways to integrate scientific knowledge, but also to train the generalists who are able to carry out this integration. It is possible that the departments for generalists training will become a distinctive feature of thirdgeneration institutions (Mokiy, 2018).

\section{References:}

1. Alekseeva, V.A. (2010). Ethnic Group. National Philosophical Encyclopedia. Available at: http://terme.ru/termin/etnos.html\#item5531

2. Mazilov, V.A. (2017). Subject of Psychological Science and Philosophy of Psychology. Fundamental and Applied Research of Modern Psychology: Results and Prospects of Development. Edited by A.L. Zhuravlev, V.A. Koltsov. Institute of psychology RAS, Moscow, p.111.

3. Mokiy, V.S. (2013). The Planet and Humanity in the Space of the Big Bang. ANOITT, Nalchik. Available at: http://tdscience.ru/images/kart/spase_and_people.zip

4. Mokiy, V.S. (2015a). Systematization and Integration of Disciplinary Knowledge in Transdisciplinary Research. Universum: Social 
Sciences.

http://7universum.com/ru/social/archive/item/2275

5. Mokiy, V.S. (2015b). Transdisciplinary Aspects of the Human Worldview. Universum: Social Sciences. 4 (14). Available at: http://7universum.com/ru/social/archive/item/2100

6. Mokiy, V.S. (2016). Transdisciplinary Method of Strengthening Interdisciplinary Synthesis of Socio-economic and Humanitarian Knowledge. Universum: Social Sciences. 8(26). Available at: http://7universum.com/ru/social/archive/item/3559

7. Mokiy, V.S. (2018). Prospects for Training Generalists in the Structure of Higher Education. Universum: Psychology and education. 3(45). Available at: http://7universum.com/ru/psy/archive/item/5600

8. Mokiy, V.S. (2019a). Using the Systemic-Transdisciplinary Approach to Enhance the Operational Reliability and Maintenance Programming of Complex Technical Objects. Transdisciplinary. Journal of Engineering \& Science, Vol. 10, pp. 133-145. Available at: http://www.atlas-tjes.org/index.php/tjes/article/view/132/125

9. Mokiy, V.S. (2019b). Systems Transdisciplinary Approach in the General Classification of Scientific Approaches. European Scientific Journal. ESJ July 2019 edition. Vol. 15, no 19, pp. 247-258. Available at: http://eujournal.org/index.php/esj/article/view/12228/11725

10. Mokiy, V.S. \& Lukyanova, T.A. (2017). Methodology of Scientific Research. Transdisciplinary Approaches and Methods. Urait, Moscow.

11. Mokiy, V.S. \& Lukyanova, T.A. (2018). Socio-Economic Development from the Position of a Systems Transdisciplinary Worldview. Collection of works of the V International Scientific and Practical Conference-Biennale. Moscow, November 21-23, 2018 (pp. 29-32). Moscow: Prometheus. Available at: https://systemeconomics.ru/sae-2018-en-plenarnoe-mokiy-lukyanova

12. Nikiforov, A.L. (2009). Analysis of the Concept of Knowledge: Approaches and Problems. Epistemology and philosophy of science. T. XXI, 3, pp. 61-73.

13. Ponomarev, L.I. (2005). Under the sign of the quantum. Fizmatlit, Moscow, p. 196.

14. Raatikainen, P. (2015). Gödel's Incompleteness Theorems. Stanford Encyclopedia of Philosophy. Available at: https://plato.stanford.edu/entries/goedel-incompleteness/

15. Surkov, V.Yu. (2019). Long State of Putin. The Independent Newspaper (11.02.2019). Available at: http://www.ng.ru/ideas/201902-11/5_7503_surkov.html 